\title{
$21 \mathrm{q}$
}

National Cancer Institute

\section{Source}

National Cancer Institute. 219. NCI Thesaurus. Code C13552.

Distal (long) arm of chromosome 21 